\title{
Redeeming Humanity from the Evil of the Jews: Islamist Rationalization of Antisemitism
}

In his book A World Without Jews: The Nazi Imagination from Persecution to Genocide, historian Alon Confino places the imagination of a world without Jews at the center of the history of the Holocaust, and he argues that the Nazis interpreted anew the past of Jewish, German, and Christian relations to fit their vision of creating a new world. ${ }^{1}$

Jews were responsible for bolshevism, communism, Marxism, socialism, liberalism, capitalism, conservatism, pacifism, cosmopolitanism, materialism, and democracy; for Germany's defeat in the First World War [...] for the Weimer's culture of entertainment [...] as well as for sexual freedom, psychoanalysis, feminism, homosexuality, and abortion. ${ }^{2}$

Confino's analysis provides the reading of Arab and particularly Islamist antisemitism with a new perspective. Imagining a world without Jews, re-interpreting past Muslim-Jewish relations and raising similar accusations against the Jews, are also major themes of Islamist imagination. In 1992, a book with same title - Alam bila yahud-was published in Cairo. The author, Egyptian intellectual 'Abd al-Mun'im al-Hufni, adopted the title from the English translation of Marx's On the Jewish Question published by Jewish philosopher Dagobert Runes. Quoting western sources like Marx, Sartre, Freud, and others, he embarked on an attempt to show that all the problems of the world, from the dawn of humanity through ancient Christianity, from the Middle Ages to the present were caused by one group - the Jews, pushing peoples to fight them and kill them. ${ }^{3}$ The logical conclusion was clear: a world without Jews will be a better place.

Twenty-five years later, a Jordanian writer, Jamal Shawaheen, warned in the Islamist Jordanian daily newspaper al-Sabil:

The elimination of the Jewish Israeli entity will therefore remain on the Arab agenda generation after generation [...] and even if today [we] are in an unfortunate state of submis-

1 A. Confino, A World Without Jews: The Nazi Imagination from Persecution to Genocide (New Haven: Yale University Press, 2014), 11.

2 Ibid., 31.

3 'Abd al-M. al-Hufni, A World Without Jews [in Arabic] (Cairo: Dar al-Rashad, 1992).

Ә OpenAccess. ( 2019 Esther Webman, published by De Gruyter. (cc) BY-NC-ND This work is licensed under the Creative Commons Attribution-NonCommercial-NoDerivatives 4.0 License. 
siveness, this will not forever be the case [...]. It can be said that, of all the peoples of the world, only the Jews lack any [common] features that make them into a people, except for their religion, and throughout history this has never been sufficient to make them into a kind of nation. They have always been, and still are, nothing but concentrations of greedy crooks. Even if wars will not defeat them today, history indicates that a million Hitlers from all over the world will [appear and] eliminate them and get rid of them forever. This will not be long in coming, because they are the problem of the whole world and not just the Arabs. $^{4}$

In the same vein, an Egyptian MP Nashwa Al-Dib asserted in a TV discussion that the Israelis will be gone like the Crusaders who were in Palestine for two hundred years. "Israel is destined to perdition," she declared. But although she referred only to Israel, she apparently meant the Jews, when she wondered: "We are 300 million Arabs. Can't we handle 15 million Jews?"5 Imam Ahmad alRawashdeh explained in a Friday sermon in Jordan that as long as the Jews are dispersed all over the land, it is impossible to annihilate them, but Allah will gather them in one place, "so that they could be dealt a mortal blow." As we see today, he continued, "after the declaration of the Jewish state [...] the Jews began to flock to Palestine [...] to meet their end, Allah willing, because they constitute an epidemic."6

These kinds of statements are abundant in the Arab antisemitic discourse, especially in times of crisis. Islamist discourse relentlessly discusses past Jewish-Muslim relations to prove the Jews' inherent vices, projecting the past on today's Jews-their character and way of thinking, and predicting their inevitable demise.

In adopting Confino's approach, it is not the intention of this essay to compare or equate Islamism and Nazism. There are scholars, such as the late historian Robert Wistrich, who engaged in such comparisons, defining Islamists as "the heirs of communism and Nazism," and claiming that they "inexorably transformed themselves into the revolutionary avant-garde of antisemitism in

4 J. Shawaheen, "The Jewish Entity [Is] the Problem of the Whole World," al-Sabil, March 18, 2017; "Jordanian Columnist in Muslim Brotherhood Daily: A Million Hitlers from all over the World Will Appear and Eliminate The Jews,” Memri, Special Dispatch no. 6890, April 23, 2017, https://www.memri.org/reports/jordanian-columnist-al-shawaheen-two-antisemitic-articles.

5 "Egyptian MP Nashwa Al-Dib: Abolish the 'Shameful' Peace Accords," Memri, Clip no. 6408, January 3, 2018, https://www.memri.org/tv/egyptian-mp-nashwa-dib-abolish-shameful-egypt-is rael-peace-accords/transcript.

6 "Imam Al-Rawashdeh in Jordan Friday Sermon Says Allah Gathered the Jews in Palestine so They Could Be Annihilated,” Memri, Special Dispatch no. 7346, February 21, 2018, https://www. memri.org/reports/imam-al-rawashdeh-jordan-friday-sermon-says-allah-gathered-jews-pales tine-so-they-could-be. 
the twenty-first century." Others defined Islamism as Islamo-fascism, rooted in Nazi ideology. ${ }^{8}$ This contested topic preoccupied and continues to preoccupy scholars of the Middle East and antisemitism, ${ }^{9}$ but this is beyond the scope of this paper.

This paper is divided into three parts. The first part is a brief introduction of the Islamist vision and the place of the Jews in it. The second part outlines two parallel debates over the roots of Arab-Muslim antisemitism and of Islamist movements which preoccupy scholars of antisemitism and Islamism, and the third part concludes by throwing light on the increasing critical Arab and Muslim voices, condemning antisemitism and prevalent conspiratorial thinking in Arab and Muslim societies, and examines whether those voices could provide clues for ways of combating antisemitism.

I contend that Islamism is an apocalyptic ideology which seeks to redeem the world from the ills of all isms-modernism, nationalism, capitalism, imperialism, socialism, communism, and the Jews. It reinforces Islam's dichotomous worldview of good and evil, believers and non-believers, the House of Islam and the House of war, which can be reconciled only with the ultimate victory of Islam. The Jews play a crucial role in this worldview. They are perceived as the spearhead of all those ills and of the enmity to Muslims and Islam, suggesting justification of genocidal measures against them to free humanity from their evil.

\section{Islamism-Historical Account}

The origins of modern day Islamism may be traced to nineteenth-century reformist Islamic movements in the Arab world and South Asia that aimed to revive Islam as a political and social force, in response to the apparent decay of Muslim societies, to the occupation of western powers and to the penetration of western secular values in Muslim culture. Believing that Muslims went astray and hence

7 R. S. Wistrich, "Anti-Zionist Connections: Communism, Radical Islam, and the Left," in Resurgent Antisemitism: Global Perspectives, ed. A. H. Rosenfeld (Indiana: Indiana University Press, 2013), 419.

8 M. Küntzel, Jihad and Jew-Hatred: Islamism, Nazism and the Roots of 9/11 (New York: Telos, 2007).

9 For the discussion of this topic see for example S. Wild, "Islamofascism?: Introduction," Die Welt des Islams: International Journal for the Study of Modern Islam 52, no. 3-4 (2012): 225-41; F. R. Nicosia and B. A. Ergene, eds., Nazism, The Holocaust, And The Middle East: Arab and Turkish Responses (New York: Berghahn Books, 2018), 1-22. 
lost their superiority, Islamic reformism since its early stages was divided into two clear trends: one that called for a gradual change and return to the pure values of early Islam, through adopting knowledge, science, and rational reinterpretation of Shari'a laws to adjust to modernity and to the new emerging circumstances. Another one discerned the same predicaments but rejected any attempt to compromise a strict literalist interpretation of Islam, embraced ideological puritanism, pan-Islamic unity and the implementation of Shari'a, and encouraged the use of force against any deviation of what is conceived as the right path, fusing politics, religion, and violence. ${ }^{10}$ The most outspoken thinkers of the first approach were Jamal al-Din al-Afghani, Muhammad 'Abduh and Rahsid Rida, ${ }^{11}$ whereas the other trend was typical of revivalist movements such as Wahhabism in the Arabian Peninsula. ${ }^{12}$

Jeffrey Bale explained that

\begin{abstract}
Islamism can be defined as a radically anti-secular and anti-“infidel” Islamic political ideology, based upon an exceptionally intolerant and puritanical interpretation of Islamic scriptures and Islamic law, which has both revolutionary and revivalist features. It can be described as revolutionary because, in order for Islamists to achieve their stated objectives, the existing international world order would have to be fundamentally transformed if not overturned, either wholly or in part. It can be characterised as revivalist because the Islamist goal is to restore the pure, pristine Islamic community that supposedly existed at the time of Muhammad and his companions (sahaba), as well as the first two generations of their successors [...]. ${ }^{13}$
\end{abstract}

Islamists developed what American intellectual Mark Lilla calls nostalgia for a glorious past, and they seek to re-establish it. "Once that is accomplished, the glorious age of the Prophet and his companions will return for good."14

10 R. L. Nettler, Past Trials and Present Tribulations: A Muslim Fundamentalist's View of the Jews (Jerusalem: Pergamon, 1987), 14-19.

11 M. Kerr, Islamic Reform: The Political and Legal Theories of Muhammad 'Abduh and Rashid Rida (Berkeley: University of California Press, 1966); A. Hourani, Arabic Thought in the Liberal Age 1798-1939 (London: Oxford University Press, 1970), 103-60, 222-44; N. Safran, Egypt in Search of Political Community (Cambridge: Harvard University Press, 1961), 75-84; N. A. Ayubi, Political Islam: Religion and Politics in the Arab World (London: Routledge, 1991); J. G. Jansen, The Dual Nature of Islamic Fundamentalism (London: Hurst, 1997).

12 D. Commins, The Wahhabi Mission and Saudi Arabia (London: I. B. Tauris, 2016); S. R. Valentine, Force and Fanaticism: Wahhabism in Saudi Arabia and Beyond (London: Hurst, 2015). 13 J. M. Bale, "Islamism and Totalitarianism," Totalitarian Movements and Political Religions 10, no. 2 (June 2009): 79.

14 M. Lilla, The Shipwrecked Mind (New York: The New York Review of Books, 2016), 142. 
One of Islamism's most prominent ideologues was Egyptian thinker Sayyid Qutb. He was a literary critic in the 1940s, who became a member of the Muslim Brotherhood, broke away from them, spent many years in prison during the 1950s and 1960s, and eventually was hung by president Gamal 'Abd al-Nasir in 1966. While in prison, he wrote his most important books which later became the cornerstone of Jihadist thought. Qutb spent nearly two years from 1948 in the US and he wrote his impressions in a three-part essay "The America I have seen" in the literary weekly al-Risala. He admired America's scientific and intellectual achievements and acknowledged its major role in the world, but he condemned what he called its shallowness, racism, and moral bankruptcy. ${ }^{15}$ "America's virtues are the virtues of production and organization, and not those of human and social leadership," he concluded. ${ }^{16}$

Qutb rejected what he perceived to be "the apologetics of Modernist Islam," whose proponents (such as Muhammad 'Abduh) accepted western standards as the ultimate gauges, and "endeavored to salvage whatever they could from the ruins by arguing that many elements of Islam are compatible with modernity."17 In his quest for authenticity, he compared the state of affairs in Muslim societies to the age of ignorance before the arrival of the Prophet-the jahiliyya. In his view, adopted by Islamists, "secularism, individualism, materialism, moral indifference, tyranny-have now combined to bring about a new jahiliyya that every faithful Muslim must struggle against, just as the Prophet did at the dawn of the seventh century." 18 His prescription to the future was "to go back to the Quran and to the manner in which it was understood and practiced by the Prophet and the first generation of Muslims (al-salaf al-salih). This meant total rejection of all man-made political, economic, legal and educational models practiced in all Muslim nations." ${ }^{19}$ Qutb saw in all those models, a hidden deception and distraction engineered by the "enemies of Believers" and Christendom. Hence, they must be removed even by force, and be ultimately replaced by Allah's sovereignty (hakimiyyat Allah) over the entire planet by conducting missionary activity

15 S. Qutb, “The America I Have Seen," Al-Risala, November 5, 1951, 1245-47; Al-Risala, November 19, 1951, 1301-6; Al-Risala, December 3, 1951, 1357-60. On his trip to America see J. Calvert, Sayyid Qutb and the Origins of Radical Islamism (London: Hurst, 2010), 139-55.

16 Qutb, "The America I Have Seen," 1360; A. Ali, "From Islamophobia to Westophobia: The Long Road to Radical Islamism," Journal of Asian Security and International Affairs 3, no. 1 (2016): 9.

17 E. Sivan, Radical Islam, Medieval Theology and Modern Politics (New Haven: Yale University Press, 1985), 67.

18 Lilla, The Shipwrecked Mind, 141.

19 Ali, "From Islamophobia to Westophobia," 9. 
(da'wa) and/or waging armed struggle (jihad) against "hypocrites," “apostates," "tyrants," "polytheists," and "unbelievers.",

The militant Islamist movements that emerged in the 1980s and 1990s, and adopted Qutb's worldview, went even further "in casting aspersions on the fidelity of rulers and, in some cases, of general Muslim populations to Islam. Although Qutb condemned the general culture of the age as 'ignorant', he avoided branding individuals kuffar ('unbelievers')."21 The ultra-radical manifestation of Islamism in the twenty-first century explains scholar Ameer Ali,

signals the recognition of the failure of that ideological alternative and represents an uncompromising determination by a new generation of Muslims to redesign Islamism and to bring Islam as a "master signifier" back to the center stage of politics, economics, society and culture. This twenty-first century Islamism, an amorphous entity splintered by objectivity and subjective elements but united in methodology of unmitigated violence, was born out of the impotence of a Muslim leadership that abysmally failed to repair injustices and humiliation inflicted upon the umma by yesterday's colonizers and today's imperialists. $^{22}$

Hence the Muslim Caliphate, which organizations such as al-Qa'ida and the Islamic State seek to reestablish, "is not only a hopeless attempt to resurrect a dead institution, but on the contrary [...] is 'a metaphor' for the struggles between Muslim aspirations to reorder the post-colonial world."23

\section{Where are the Jews in this Worldview?}

The Jews did not preoccupy the Islamic reformists at the end of the nineteenth century, but they could not ignore them in their attempts to define the place of non-Muslims in their Islamo-national vision and especially in view of the emerging conflict between the Arabs and the Jewish-Zionist settlers in Mandatory Palestine. Islamic modernist Rashid Rida, for example, praised the solidarity among Jews, their determination to help each other and raise money for collective goals at the beginning of the twentieth century. ${ }^{24}$ However, by 1934, he developed a

20 On Sayyid Qutb's worldview see Calvert, Sayyid Qutb and the Origins of Radical Islamism.

21 Ibid., 15.

22 Ali, "From Islamophobia to Westophobia," 12.

23 Ibid., 15.

24 See for example, R. Rida, "The Jews in France and in Egypt," al-Manar 1, no. 2 (1898): 35-55; R. Rida, "The Life of a Nation After Its Death," al-Manar 4, no. 21 (1902): 801-9. S. G. Haim, “Arabic Antisemitic Literature. Some Preliminary Notes," Jewish Social Studies 17, no. 4 (October 1995): 309-10; S. Haim, "The Palestine Problem in al-Manar," in Egypt and Palestine: 
strong antipathy to Zionism which verged on antisemitism, and adopted the spirit and the letter of the Protocols of the Elders of Zion without explicitly mentioning them, due to the conflict in Palestine. ${ }^{25}$ Influenced by the reformist movement, the Muslim Brotherhood movement, which was founded in 1928 by Hasan al-Banna, and its radicalized offshoots since the 1970s placed Palestine at the core of its Islamist ideology. ${ }^{26}$ However, up until the 1967 War, they exposed "a sort of disdainful disregard for Jews and Israel."27 The Arab defeat in the 1967 War was interpreted by the Islamists as the defeat of the nationalist project and caused a split in the rank and file of the Muslim Brotherhood, which coincided with Qutb's new ideas, and with a generational gap that led to the formation of radical Jihadist movements. Again, it was Sayyid Qutb who contributed to the ideological rationalization of the hatred of the Jews. He allotted them a special role as the ultimate enemies of Islam and Muslims since early Islam, and considered the conflict in Palestine a pivot war in the "struggle between the resurgent East and the barbaric West, between God's law for mankind and the law of the Jungle."28 However, he prioritized Islamism's principal goals as toppling existing heretic Arab rulers, establishing an Islamic order, and then dealing with Israel.

The Jews were perceived by him and by the radical movements that adopted his vision not only as the epitome of evil from time immemorial but also as the symbol of the modern world, who spread atheism, instigated revolutions, and invented corrupted ideologies:

One single line inexorably connects the battles and the fighting of the Prophet against the Arab idolaters and Jews of $7^{\text {th }}$ century Arabia, the crusades of later medieval times, modern Western colonialism, and the current day conflict between Zionism and the Arab-Islamic

A Millennium of Association (868-1948), ed. A. Cohen and G. Baer (Jerusalem: Yad Izhak BenZvi, 1984), $300-305$.

25 R. Rida, "A Lecture at The Association of Muslim Youth,” al-Manar 34 (1934): 208. See also Haim, "Arabic Antisemitic Literature," 307-12; Haim, "The Palestine Problem in al-Manar," 299-313; Jansen, The Dual Nature of Islamic Fundamentalism, 120-21.

26 On the Muslim Brotherhood, see R. P. Mitchell, The Society of the Muslim Brothers (New York: Oxford University Press, 1993); Abd al-F. M. al-'Uwaisi, The Muslim Brothers and the Palestine Question 1928-1947 (London: Taurus Academic Studies, 1998); Jansen, The Dual Nature of Islamic Fundamentalism, 123-37.

27 E. Sivan, "Islamic Fundamentalism, Antisemitism and Anti-Zionism," in Anti-Zionism and Antisemitism in the Contemporary World, ed. R. S. Wistrich (London: Macmillan, 1990), 76; E. Sivan, “A Resurgence of Arab Antisemitism?,” in Survey of Jewish Affairs, 1988, ed. W. Frankel (London: Associated University Presses, 1989), 87.

28 S. Qutb, “The American Conscience...and the Palestinian Case," al-Risala, no. 697 (October 21, 1946): 1156, as quoted in Calvert, Sayyid Qutb and the Origins of Radical Islamism, 120. 
world. In fact, both sides do not have any choice but to participate in this inevitable and eternal struggle between good and evil. ${ }^{29}$

Qutb, according to Bassam Tibi, "reads the European Antisemitism into Islamic history to give it through selective religious arguments an Islamic authentic shape. ${ }^{30}$

Qutb's famous essay Our Struggle with the Jews (ma'rakatuna ma'a al-yahud) "is a rounded and concentrated expression of his thoughts on the Jews." ${ }^{31}$ Written and probably published first in the early 1950s and reprinted in 1970 by the Saudi Arabian government, it reflected his deep enmity toward the Jews as the embodiment of all things anti-Islamic. "The Muslim Community continues to suffer from the same Jewish machinations and double-dealings which discomfited the Early Muslims, ${ }^{32}$ he clarified in his opening sentence. Nettler identifies three perspectives in Qutb's discussion on the Jewish question:

(1) the Jewish goal of Islam's destruction: Islam past trials and present tribulations with the Jews. (2) The true nature of the Jews. (3) The real balance of power and the solution. Or, despite the Jews' evil intent toward Islam they would be unable to withstand the will of the Muslim Community-if the Muslims would only be real Muslims. ${ }^{33}$

In Qutb's view, the "Jewish campaign against Islam was being conducted from two sides, the physical and the spiritual. The former was a bodily and material struggle against Islam's society, polity and civilization. The latter was an attack on Islam's system of belief."34 "Perhaps the most critical point of Qutb’s diagnosis of the Jewish threat was that they had infiltrated Muslim society." ${ }^{35}$ They carry Muslim names, but actually they are Jews in disguise who fulfill the ancient role of the Jews as the Muslims' worst enemy: they conspire against

29 M. Ebstein, In the Shadows of the Koran: Said Qutb's Views on Jews and Christians as Reflected in his Koran Commentary (Washington: Hudson Institute, 2009), 13.

30 B. Tibi, "From Sayyid Qutb to Hamas: The Middle East Conflict and the Islamization of Antisemitism," in Global Antisemitism: A Crisis of Modernity IV, ed. C. A. Small (New York: ISGAP, 2013), 12.

31 Nettler, Past Trials and Present Tribulations, v. Nettler's book provides a full translation of Qutb's essay, 72-89. S. Qutb, Our Struggle with the Jews [in Arabic] (Cairo: Dar al-Shuruq, 2001).

32 Nettler, Past Trials and Present Tribulations, 72.

33 Ibid., 30.

34 Ibid., 34.

35 J. T. Kenney, "Enemies Near and Far: The Image of the Jews in Islamist Discourse in Egypt," Religion 24, no. 3 (1994): 256. 
Islam from within to sow doubt and suspicion about it in the Muslim community. ${ }^{36}$

The Jews also harbor hatred for others, "and they just wait for humanity to meet with disaster [...]. All of this evil arises only from their destructive egoism." "37 For example, they were behind the doctrine of atheistic materialism; the doctrine of animalistic sexuality; the destruction of the family and the shattering of sacred relationship in society. ${ }^{38}$ For their evil-doing, Allah punished them and brought upon them humiliation and expulsion more than once, explained Qutb. Hitler was his last servant, but they returned to evil-doing in the form of Israel, and they will be meeting their punishment again. ${ }^{39}$ Although Qutb did not explicitly call for the annihilation of the Jews, as later Islamists did, they were perceived as a threat not only to Islam and the Muslims but also to Christianity and to all of humanity. Therefore, as David Patterson contends, "they fall outside the possibility of conversion and redemption." 40

The stigmatization of the Jews as "essentially evil" and the division of the world between good and evil, which characterize Islamist ideology, are also typical to any Manichean worldview. "For Manicheans, the demonic enemy personifies whatever is most reviled [...] That can be a 'soft' government, a protest movement, unruly legislature, the press, the intelligentsia, 'permissiveness."' The Satanic Jew of antisemitic fantasy is often a kind of composite stereotype of all these forces, ${ }^{41}$ and "serve as an explanatory master key" ${ }^{42}$ for all disasters. ${ }^{43}$

It should be stressed, however, that although Muslims have always viewed Islam as a superior religion, superseding Judaism, they did not consider Jews as heretics which required eradication as long as they did not challenge Islamic rule. By insisting on maintaining the State of Israel and by rejecting the Islamist

36 Nettler, Past Trials and Present Tribulations, 76-7; Qutb, Our Struggle with the Jews, 26; Calvert, Sayyid Qutb and the Origins of Radical Islamism, 168.

37 Nettler, Past Trials and Present Tribulations, 79. Qutb, Our Struggle with the Jews, 29.

38 Nettler, Past Trials and Present Tribulations, 83; Qutb, Our Struggle with the Jews, 34.

39 Nettler, Past Trials and Present Tribulations, 86-7; Qutb, Our Struggle with the Jews, 37.

40 D. Paterson, "The Muslim Brotherhood and the Evolution of Jihadist Antisemitism," ISGAP Flashpoint 50, January 17, 2018, https://isgap.org/flashpoint/the-muslim-brotherhood-and-theevolution-of-jihadist-antisemitism/.

41 D. N. Smith, "The Social Construction of Enemies: Jews and the Representation of Evil," Sociological Theory 14, no. 3 (November 1996): 233.

42 Ibid., 234.

43 E. Karsh, "The Long Trail of Islamic Antisemitism," in Islamic Attitudes to Israel, ed. E. Karsh and P. R. Kumaraswamy (Milton Park: Routledge, 2008), 3. 
peace offer to live as a protected minority under Islamic rule, the Jews have forfeited their right to exist. ${ }^{44}$

The radicalization of Islamist groups in Egypt, who adopted Qutb's Muslimcentered and violent vision in the 1970s and 1980s, also entailed the adoption of his view of the Jews. However, "they ceased, or at least significantly lowered the level, of anti-Jewish rhetoric." 45 The struggle against the Jews and Zionism was postponed to a later stage, after the accomplishment of their goals in changing Muslim societies. Jihad against "the Crusaders and the Jews" was also a major theme in the ideology of global Jihadist movements, such as al-Qa'ida and its offspring ISIS, and constitutes a crucial stage in a long campaign for the restoration of the Muslim Caliphate and the establishment of an Islamic world order. The Jews, in their perception as well, are not only the occupiers of Muslim lands in Palestine but are part of the western Judeo-Christian civilization, which constitutes a threat to Islamic civilization and Islamic revival.

In his "Declaration of the World Islamic Front for Jihad against the Jews and the Crusaders" of February 23, 1998, Osama bin Laden deemed jihad as "an individual duty for every Muslim who can do it," 46 similar to Hamas in their Charter. ${ }^{47}$ On the eve of the Iraq War, bin Laden described the Jews in a broadcast on February 11, 2003, as the same ones that had lied and tried to trick the Creator, killed the Prophets, and had broken their promises. The Jews were the lords of usury and leaders of treachery, who believed that humans were their slaves. In conclusion, he repeated the oft-quoted saying (hadith) about Judgment Day, whereby Jews would hide behind rocks and trees, which would call on the Muslims to come and kill them. This hadith, he stressed, indicated that the battle would be face-to-face and that the Muslims would emerge victorious in their jihad against the Crusaders and the Jews. ${ }^{48}$

Although seen also as the spearhead of the West in the war against Islam, the Jews and the issue of the Arab-Israeli conflict were not al-Qa'ida's nor ISIS’s first priority. Whereas al-Qa'ida was more concerned with the American

44 M. Maqdsi, “Charter of The Islamic Resistance Movement (Hamas) of Palestine," Journal of Palestine Studies 22, no. 4 (Summer, 1993): 122-34, articles 13, 9, and 7.

45 Kenney, "Enemies Near and Far," 260.

46 Al-Quds al-'Arabi, February 23, 1998; al-Hayat, February 24, 1998. See also B. Lewis, "License to Kill," Foreign Affairs 77, no. 6 (November-December 1998): 9-14; E. Webman, "The Polarization and Radicalization of Political Islam,” in Middle East Contemporary Survey, XXII: 1998, ed. B. Maddy-Weitzman (Boulder: Westview, 2001), 129-31.

47 Maqdsi, "Charter of The Islamic Resistance Movement (Hamas) of Palestine."

48 Al-Quds al-'Arabi, February 21, 2003; "Bin Laden's Sermon for the Feast of the Sacrifice," Memri, Special dispatch 476, March 6, 2003, https://www.memri.org/reports/bin-ladens-ser mon-feast-sacrifice. 
presence in Saudi Arabia and Iraq, ISIS sought to reshape the geographic boundaries of the Middle East, establish its version of Shari'a rule, and unite the Muslim world before it turns its guns against the United States, Europe, and Palestine. ISIS believed that it must first weed out apostates and "fake" Muslims, a definition that covers anyone standing against them. As a result, ISIS was accused by its opponents of being Mossad agents and Abu Bakr al-Baghdadi was accused of being a Jew. ${ }^{49}$ However, Jewish communities in the West were a legitimate target of Jihadists since the early 1990s. In the wake of its territorial retreat since 2014, ISIS is redefining its priorities and its strategic goals, meanwhile encouraging its Muslim followers and sympathizers to act where they live-a strategy that al-Qaida pursued before it. ${ }^{50}$

\section{Debates on Islamism and Antisemitism}

What are the roots of the radical, violent Islamist vision and its attitudes towards the Jews? There seem to be two separate parallel debates on these issues-one, on the roots of Islamist ideology and violence, and the other on the roots of antisemitism in Arab and Muslim societies in general and in the Islamist worldview in particular. But these debates have some common characteristics, and they are entangled with each other. They both seek the roots to better understand the phenomena they discuss, and they are driven by the urge to find ways to combat them, which make them at times susceptible to bias and misinterpretation.

The first wave of debates on Islamism or political Islam, as it was referred to, took place since the mid-1980s in the wake of the emergence of Islamic regimes and radical Islamic movements in the Middle East and North Africa. It evolved around questions such as:

49 "Syrian Minister of Culture Issam Khalil: Jehovah and ISIS Use the Same Terrorist Methods," Memri, Clip no. 4546, October 3, 2014, http://www.memritv.org/clip_transcript/en/4546.htm; "Veterans Today: Da'ish Leader is Jewish and a Mossad Agent," Iranian Student's News Agency, September 10, 2014, http://www.isna.ir/fa/news/93051607502/; "Daish: Allah Did Not Order Us to Fight Israel,” al-Masri al-Yawm, July 9, 2014, http://www.almasryalyoum.com/news/details/ 479626; “Claims That ISIS Has Jewish Roots Grow In Muslim World,” Anti-Defamation League, August 26, 2015, http://blog.adl.org/intenational/claims-that-isis-has-jewish-roots-grow-in-mus lim-world.

50 E. Webman, "Al-Qa'ida and the 'Arab Spring': Redefining Its Modus-Operandi," Tel Aviv Notes 6, no. 23, December 10, 2012, https://dayan.org/content/tel-aviv-notes-al-qaida-andarab-spring-redefining-its-modus-operandi; D. Porat, ed., Antisemitism Worldwide, General Analysis 2015 (Tel Aviv: Tel Aviv University, Kantor Center 2016), 32-36, 59, http://kantorcenter.tau.ac. il/sites/default/files/Doch2015-\%20 \%28160117\%29.pdf. 
Is Islamism driven by religious fervor, social protest, or nationalist xenophobia? Is the rise of Islamism a threat to stability, tolerance, and order? Or, is it the first step towards reform, participation, and democratization? Does repression of Islamist radicalize them or tame them? Are Islamists in power guided by their ideals or their interests? Should the governments in the West base their policy on human rights or realpolitik? Does Islamism have the momentum to remake the future, or is it a rearguard action that is already failing? ${ }^{51}$

These were some of the questions that had been raised, as Martin Kramer thoroughly defined.

The second wave of debates on Islamism and terrorism was the result of the rise of global-Jihadist movements at the turn of the twentieth century, which reached its peak with the declaration of the Islamic State of Iraq and Syria (ISIS) in 2012 and the collapse of law and order in several Middle Eastern states in the wake of the so-called "Arab Spring." ${ }^{52}$ It dealt with similar questions, but due to the pervasive violence and the growing Muslim presence in the West, this wave of debates focused more on the roots and uniqueness of Islamism and violence, introducing a wide range of interpretations. Some saw them as an exclusive Islamic phenomenon, whose roots are purely Islamic and sectarian, ${ }^{53}$ while others considered them as part of global radical and violent social movements in reaction to identity crises, the crisis of enlightenment and globalization processes, in which Islam is only one component, if at all. Even ISIS's violence was presented as an additional link in the barbaric violence and genocides of the twentieth century, including the Holocaust. ${ }^{54}$ Mehdi Hasan even insisted that

to claim that ISIS is Islamic is egregiously inaccurate and empirically unsustainable, not to mention insulting to the 1.6 billion non-violent adherents of Islam across the planet. Above

51 M. Kramer, ed., The Islamism Debate (Tel Aviv: Tel Aviv University, 1997), 7.

52 See for example, A. Bayat, "Islamism and Empire: The Incongruous Nature of Islamist Anti-Imperialism," Socialist Register 44 (2008): 38-54.

53 See for example, S. Moubayed, Under the Black Flag: At the Frontier of the New Jihad (London: I. B. Tauris, 2015); G. Wood, “What ISIS Really Wants,” Atlantic, March 2015, https://www. theatlantic.com/magazine/archive/2015/03/what-isis-really-wants/384980/; S. Mabon and S. A. Royle, The Origins of ISIS: The Collapse of Nations and Revolution in the Middle East (London: I. B. Tauris, 2017).

54 See for example, P. Rogers, Irregular War: ISIS and the New Threat from the Margins (London: I. B. Tauris, 2016); B. H. Fishman, The Master Plan: ISIS, al-Qaeda, and the Jihadi Strategy for Final Victory (New Haven: Yale University Press, 2016); M.W. S. Ryan, Decoding Al-Qaeda's Strategy: The Deep Battle Against America (New York: Columbia University Press, 2017); F. Devji and J. B. Mohaghegh, "Point of No Return: Extremism, Sectarian Violence, and the Militant Subject,” JSCTIW Interlocutors Series, SCTIW Review (September 3, 2014). 
all else, it is dangerous and self-defeating, as it provides Baghdadi and his minions with the propaganda prize and recruiting tool that they most crave..$^{55}$

French social scientist Olivier Roy parallels Jihadists to the radical Left in Europe in the 1960s and 1970s. The two movements, he claims, derive from the same social swamp of alienated restless youth. Although the Jihadist-Salafists believe that they represent Islamic tradition, their violence "has more to do with a Western tradition of individual and pessimistic revolt for an elusive ideal world than with the Koranic conception of martyrdom," he concludes. ${ }^{56}$

In his book The Shipwrecked Mind, Lilla agrees that "there is little that is uniquely Muslim in the myth of an imagined glorious past, but claims that political Islamists, resemble European nationalists, and the American right in 'their ideological tale.." 57 "Even its success in mobilizing the faithful and inspiring acts of extraordinary violence has precedents in the Crusades and in the Nazi efforts to return to Rome by way of Walhalla," he concludes. ${ }^{58}$ Political nostalgia is the force "that shaped the imaginations of all the political thinkers and ideological movements in the twentieth century," 59 and that inspires "dreams of a modern caliphate with global ambitions" in Islamist imagination. ${ }^{60}$

Muslim and Arab scholars, such as Faisal Devji and Mohammed Ayoob, also place al-Qa'ida and ISIS on a spectrum of global, radical, and violent social movements, as a reaction to identity crises beyond the crisis in the Middle East and the Muslim World. ${ }^{61}$ Bader al-Ibrahim and Sami Zubaida acknowledge the role of Islamic doctrines in the Islamist ideology but attribute no less importance to external factors-leftist and nationalist perceptions, such as anti-impe-

55 M. Hasan, "How Islamic Is the Islamic State? Not at all. What the Atlantic Got Wrong about ISIS,” The New Republic, March 13, 2015, https://newrepublic.com/article/121286/how-islamicislamic-state.

56 O. Roy, Globalised Islam: The Search for a New Ummah (London: Hurst, 2004), 43. M. Rodenbeck, "The Truth About Jihad," The New York Times Review of Books, August 11, 2005, http:// www.nybooks.com/articles/2005/08/11/the-truth-about-jihad/. O. Roy, "Who Are the New Jihadis?,” The Guardian, April 13, 2017.

57 Lilla, The Shipwrecked Mind, xiii.

58 Ibid., 142.

59 Ibid., xvi.

60 Ibid., xx.

61 M. Ayoob, “Challenging Hegemony: Political Islam and the North-South Divide," International Studies Review 9 (2007): 629 - 43; F. Devji, “Al-Qaeda, Spectre of Globalisation,” Soundings, A Journal of Politics and Culture 32 (Spring 2006): 18-27. 
rialism, Israeli occupation, western hegemony, liberal economy, and globalization, which drive anarchistic movements and populist rhetoric. ${ }^{62}$

However, despite the resemblance between Islamist-Jihadist movements and various shades of western radical movements, the Islamic background and the particular causes that led to their emergence and the content of Islamist ideology are crucial to any attempt to properly understand and explain the phenomenon of Islamism and global Jihadism. "Islamism, including Jihadism, is inconceivable without reference to Islam."63 Bale criticizes much of the literature which was published since the 1979 Islamic Revolution, and even more since 9/11, as embodying

problematic conceptual perspectives that can be best characterized as "Islam bashing" [conflating Islam with Islamism], "Islam apologism" [claiming that Islam is a religion of peace, that all religions are equally prone to produce extremists], or-worst of all-“Islamist apologism" [dismissing any connection between Islamism and Islam] ${ }^{64}$

Distorted perspectives guided political leaders as well. Historian Jeffrey Herf accuses the leaders in democracies since 9/11 of refraining from stating in public what they knew to be true in private concerning the connections between Islam, Islamism, and terror. They were cautious, he contends, for a variety of reasons,

including not offending Muslims, gaining support from Muslim communities for counterterrorism intelligence operations, avoiding fanning hostility to Muslims in democracies and being accused of Islamophobia. Such a policy was thought to be realistic to avoid the "clash of civilizations" that Islamist terror organizations were trying to foster. ${ }^{65}$

Similarly problematic is ignoring the Jewish component in Islamist ideology among scholars of Islamism who discuss Islamist Westophobia-an extreme antipathy towards the West, without considering the role of the Jews in their perception of Judeo-Christian civilization. ${ }^{66}$

62 S. Zubaida, “Trajectories of Political Islam," Index of Censorship 4 (1996): 150 - 57; B. al-Ibrahim, "ISIS, Wahhabism and Takfir," Contemporary Arab Affairs 8, no. 3 (July-September 2015): $408-15$.

63 Bale, "Islamism and Totalitarianism," 77.

64 Ibid., 73.

65 J. Herf, “Realism, Islamism, and Counterterrorism,” The National Interest, June 7, 2017, http:// www.meforum.org/6755/realism-islamism-and-islam-when-will-difficult.

66 See for example A. Mirsepassi, "Religious Intellectuals and Western Critiques of Secular Modernity," Comparative Studies of South Asia and the Middle East 26, no. 3 (2006): 416-33. 
Islamism and Islamist movements are also fervently discussed in Arab public discourse, and it seems in contrast to the trend among western scholars and commentators, which tend to minimize the impact of Islamic culture and religion on the emergence of Islamism, there is a growing awareness among Arab writers that the ideas and goals embedded in Islamism derive from canonical traditional Sunni Islam, and the differences between them are only in methods and style. Khalid al-Hurub, an Arab scholar spoke of "a pleasant ISISm," represented by al-Azhar, the highest authority of Sunni Islam, versus ISIS's "barbaric ISISm." 67 Those Jihadists, acknowledged another writer, "belong to the same tree-and all of them stem from the Arabs' civilizational ills. The Islamic State, like al-Qaeda, is the tumorous creation of an ailing body politic." ${ }^{68}$ Fighting it requires a revolution in Islamic thought and discourse, and a new relationship between religion and modernity. "We are in need of a religious revolution," declared Egyptian president "Abd al-Fattah al-Sisi in a gathering of religious scholars in January $2015 .^{69}$

This insight is permeating into growing audiences in view of ISIS's conduct and its repercussions in Arab societies. "Your fatwa does not apply here" was a call of young Muslims resisting IS and its ilk. ${ }^{70}$ ISIS succeeded in exploiting the existing sectarian, religious, and tribal structure for its own ends, and its ideology threatens not only the shaky Middle Eastern state system but also the religious institutions. Killing Muslims, fanning inter-sectarian conflicts and a rigid subversive ideology converged to create revulsion from Islamism, which is reflected in the Arab public discourse in the press and social media, as well as in official political statements, and even re-interpretation of Islamic jurisprudence. $^{71}$

67 Al-Hayat, March 15, 2015.

68 H. Melhem, "The Barbarians Within Our Gates," Politico Magazine, September 18, 2014, https://www.politico.com/magazine/story/2014/09/the-barbarians-within-our-gates-111116.

69 R. Ibrahim, "Egypt's Sisi: Islamic 'Thinking' is Antagonizing the Entire World," Middle East Forum, January 1, 2015, https://www.meforum.org/articles/2015/egypt-s-sisi-islamic-thinking-isantagonizing.

70 See for example, K. Bennoune, Your Fatwa Does not Apply here: Untold Stories from the Fight against Muslim Fundamentalism (New York: W. W. Norton, 2013).

71 See for example, W. 'Abd al-Rahman, "The Mufti of Jordan: The 'Ulama Should Agree on One Discourse to Fight the Takfiri Thinking," al-Sharq al-Awsat, December 21, 2014; "Al-Azhar: The Islamic State (ISIS) is a Terrorist Organization, but it Must not be Accused of Heresy," Memri, Special Dispatch, no. 5910 (December 21, 2014), https://www.memri.org/reports/al-azhar-is lamic-state-isis-terrorist-organization-it-must-not-be-accused-heresy; E. Landau-Tasseron, "Delegitimizing ISIS on Islamic Grounds: Criticism of Abu Bakr al-Baghdadi by Muslim Scholars,” In- 
A parallel debate is going on among scholars of antisemitism on the roots of Arab/Muslim antisemitism. At first glance, it seems that there is no connection between the two debates, but in fact they exhibit similar problematics-lack of a conceptual perspective that can introduce a balanced interpretation of the two phenomena without being accused of "Islam/Muslim-bashing," "Islamapologism,” or "Islamist-apologism.” German scholar of Islamic studies Gudrun Krämer, accurately explained that there are few topics more sensitive and controversial than antisemitism in the Muslim world, and researchers in the field "have long hesitated to touch it, be it out of fear to be branded as enemies of Islam, or alternatively, as antisemites." 72 At one end of the spectrum are scholars such as Andrew Bostom, an American author and associate professor of medicine at Brown University, who claims that the phenomenon of Muslim Jew-hatred dates back to the origins of Islam and is embedded in Islamic doctrines and history. "When I put together the Koranic verses on the Jews, they read like an indictment, prosecution and conviction [...] antisemitism cannot be explained by cultural influences but is, in fact, inherently Islamic."73 At the other end is associate professor for Modern Middle Eastern History at Maryland University, Peter Wien, who insists that there is no tradition of antisemitism in Islam and that Europeans brought antisemitism to the Arab World. ${ }^{74}$

This controversy has been extensively discussed by several scholars. ${ }^{75}$ Summarizing the conflicting views in the debate of antisemitism, social psychologist Neil Kressel accurately explained that one side in this debate,

quiry and Analysis, no. 1205 (November 19, 2015), http://www.memri.org/publicdocs/MEMRI_IA_ 1205_Delegitimizing_ISIS_On_Islamic_Grounds-FINAL.pdf.

72 G. Krämer, “Antisemitism in the Muslim World. A Critical Review,” Die Welt des Islams, 46, no. 3 (November 2006): 243.

73 S. Ser, "A Simmering Hatred, Interview with Andrew G. Bostom," The Jerusalem Post, June 20, 2008, https://www.andrewbostom.org/2008/06/jerusalem-post-interview-with-sam-ser/. A. G. Bostom, ed., The Legacy of Islamic Antisemitism: From Sacred Texts to Solemn History (New York: Prometheus Books, 2008), 33.

74 P. Wien, “There is no Tradition of anti-Semitism in Islam,” Qantara, May 23, 2018, https://en. qantara.de/content/anti-semitism-there-is-no-tradition-of-anti-semitism-in-islam.

75 See for example N. J. Kressel, "The Sons of Pigs and Apes": Muslim Antisemitism and the Conspiracy of Silence (Washington: Potomac Books Inc., 2012), 122-27; C. Heni, Antisemitism: A Specific Phenomenon: Holocaust Trivialization-Islamism-Post-colonial and Cosmopolitan anti-Zionism (Berlin: Edition Critic, 2012), 482-500; M. Küntzel, "The Roots of Antisemitism in the Middle East: New Debates," in Resurgent Antisemitism: Global Perspectives, ed. Alvin H. Rosenfeld, (Indiana: Indiana University Press, 2013), 382-98; Karsh, “The Long Trail of Islamic Antisemitism”; E. Webman, “Treading in Troubled Waters: Seeking the Roots of Muslim Antisemitism," Bustan. The Middle East Book Review 4, no. 2 (2013): 113-36. 
which might be labeled the received wisdom, sees Jew-hatred as essentially alien to Islamic history and culture. Here, experts may acknowledge a variety of negative references to Jews in the Islamic religious literature and occasional antisemitic incidents through the years, but they portray Islamic political and social traditions as fundamentally tolerant, at least when judged by the standards of their day [...]. They see antisemitism mainly as a European import, brought to the Muslim world by manipulative European antisemites and fueled by the Arab-Israeli conflict. ${ }^{76}$

On the other side of the debate,

the challengers of the received wisdom acknowledge that Jews at times fared tolerably well under Muslim rule in some places; however [...] these scholars assign more weight to hostile statements and incidents concerning Jews in the Quran, hadiths, and other religious documents of Islam. Moreover [...] [they] argue that a considerable body of anti-Jewish material, significant anti-Jewish discrimination, and substantial violence preceded the modern Israeli state and Zionism for centuries and sprouted from seeds planted at the very inception of Islam. ${ }^{77}$

There is no definite conclusion to this controversy as well. But, it seems that scholars of Islam and the Middle East agree that "Islamic culture includes natural antipathy directed against Jews [...] that arose from the phenomena associated with the emergence of new religions [...] [and] that antipathy is embedded in the Qur'an, the Hadith, and most forms of traditional literature."78 However, this antipathy was not constantly translated into operational action against the Jews under Muslim rule until modernity, and Muslim aversion toward the Jews "had neither the particular qualities nor the virulence of Christian antipathy toward Jews." ${ }^{\text {"79 }}$ Reuven Firestone suggests that latent antisemitism becomes activated when life becomes difficult and people's hopes and dreams are frustrated,

76 Kressel, "The Sons of Pigs and Apes," 122.

77 Ibid., 123. In addition to the debate on the roots of Arab antisemitism and its relation to the Arab-Israeli conflict, an ongoing debate evolves around the centrality of antisemitism in Islamist ideology, and the impact of Nazism on its development. See for example, M. Küntzel, Jihad and Jew-Hatred; J. Herf, Nazi Propaganda for the Arab World (New Haven: Yale University Press, 2009); E. Webman, "The Challenge of Assessing Arab/Islamic Antisemitism," Middle East Studies 46, no. 5 (September 2010), 677-97.

78 R. Firestone, "Islamophobia and Anti-Semitism: History and Possibility," Arches Quarterly 4, edition 7 (Winter 2010): 49.

79 R. Firestone, "Contextualizing Antiemitism in Islam: Choseness, Choosing, and the Emergence of New Religion," in Not Your Father's Antisemitism: Hatred of the Jews in the $21^{\text {st }}$ Century, ed. M. Berenbaum (St. Paul: Paragon House, 2008), 137; D. Nirenberg, Anti-Judaism. The Western Tradition (New York: W. W. Norton, 2013), 177-78. See also B. Lewis, Semites and Antisemites (London: Phoenix Giant, 1997), 117-39. 
when there is a need to blow off steam or find scapegoats for serious disappointment and aggravation. Then, "ancient slanders are re-discovered, old writings and complaints are renewed and stereotypes images revived. The result is the restoration of an old prejudice in new clothes." 80 Jonathan Judaken as well concedes that antisemitic codes "serve as short cut to explain the operational forces of anxiety in people's lives, when they do not have the language or analytic sophistication to name them properly."81

Indeed, the encounter with modernity, and the growing European political and cultural penetration of the Middle East in the nineteenth century, challenged the extant political, social, cultural, and economic order in the region and created a deep sense of crisis in the Muslim world. Coupled with the emergence of Arab nationalism and Zionism, Jewish immigration to Palestine, and the later trauma of Arab defeats, this enhanced the anti-Jewish hostility and led to the entrenchment of antisemitic perceptions. The Arab antisemitic discourse developed a uniqueness and authenticity that differentiates it from western antisemitism. While borrowing themes from it, the sources and motivation of Arab-Muslim antisemitism were indigenous, stemming from religious and nationalist sentiments, thereby producing a unique symbiosis of Islamic anti-Jewish motifs and classical western antisemitic tropes, deriving from Christianity, and from the repository of racist and political antisemitism.

\section{Conclusion-Arabs and Muslims Criticizing Antisemitism and Holocaust Denial}

Although Islamists continue to envision a world without Jews, and despite the widespread antipathy toward the Jews and the continued rejection of Zionism and Israel in Arab and Muslim societies, there are increasing Arab and Muslim voices that criticize antisemitism and even look at the Jews and Israel as a model worthy of appreciation and emulation. Criticism of antisemitism is part of a selfcritical literature, which bemoans the inability of Arab and Muslim societies to overcome their differences and solve their acute predicaments. It increased in the mid-1990s when it seemed that globalization and normalization of relations with Israel would usher a new era of democratization and liberalization; in response to the rise of global Jihadist movements at the turn of the twenty-first

80 Firestone, "Islamophobia and Anti-Semitism," 45.

81 J. Judaken, “So What's New? Rethinking the 'New Antisemitism' in a Global Age," Patterns of Prejudice 42, nos. 4-5 (2008): 546. 
century; and in the wake of the so-called "Arab Spring" in 2011. The "Arab Spring" and the new nexus between Islamism and terrorism, embodied in ISIS (Islamic State of Iraq and Syria) exacerbated self-criticism in Arab and Muslim societies, which incorporated criticism of the belief in conspiracy theories and of the antisemitic discourse associated with it. ${ }^{82}$

"We should reconsider our notions regarding the Jewish question [...] We are not even aware how much this affects us," admitted Egyptian philosopher Youssef Zeidan in an interview on December 30, $2013 .{ }^{83}$ "It is impossible to understand what is going on in the Arab countries as long as we continue to write 'Israel' in inverted commas. Israel is a fundamental part of the picture [...] Our first and foremost problem is internal, with our heritage," explained the well-known Syrian poet Adonis in an interview in August 2017. ${ }^{84}$ This realization of the central role of the Jews in the Arab and Muslim attempts to explain the world around them, by a growing number of Arab intellectuals is perhaps the first step toward a fresh thinking about Jews, Israel and Jewish-Muslim relations. Articles rejecting antisemitic generalizations regarding the nature of the Jews based on religious sources as unfit to the present circumstances, ${ }^{85}$ or "antithetical to the teachings of Islam," 86 and calling to abandon hatred and hostility towards Jews in Arab cultural and official discourse ${ }^{87}$ became more frequent.

This critical approach toward Arab societies and Arab antisemitism also included criticism of the Arab discourse on the Holocaust, especially its widespread denial. ${ }^{88}$ Visiting Holocaust museums, visiting concentration camps, calling for Holocaust education in Arab schools are all part of this trend, although it

82 See for example, E. Webman, "From the Damascus Blood Libel to the 'Arab Spring': The Evolution of Arab Antisemitism," Antisemitism Studies 1, no. 1 (Spring 2017): 157-206.

83 J. Hugi, "Egyptian Intellectuals Call for Fresh Thinking about 'Jewish Question'," al-Monitor, January 17, 2014, https://www.al-monitor.com/pulse/ru/originals/2014/01/youssef-zeidan-in tellectual-egypt-israel-relations.html.

84 "Syrian Poet Adonis: There Can Be No Democracy in the Arab World under Present Circumstances,” Memri, Clip no. 6185, August 11, 2017, https://www.memri.org/tv/syrian-poet-adonisno-democracy-in-arab-world-people-undergoing-extinction.

85 S. al-Qahtani, al-Jazira, July 23, 2016; "Articles in Saudi Press: End the Antisemitic Discourse, Learn from the Jews’ Success,” Memri, Special Dispatch, no. 6574, August 14, 2016, https://www. memri.org/reports/articles-saudi-press-end-antisemitic-discourse-learn-jews-success-0.

86 L. Speyer, "Prominent American Islamic Scholar Calls 'Horrific' Antisemitism Rampant among Muslims Antithetical to their Religion,” Algemeiner, January 3, 2017.

87 Y. Hijazi, al-Jazira, July 30, 2016; “Articles in Saudi Press,” Memri.

88 For a broader discussion of the new approach see: M. Litvak and E. Webman, From Empathy to Denial: Arab Responses to the Holocaust (Jerusalem: The Hebrew University Magnes Press, 2015), 331-38 [in Hebrew]; E. Webman, "Old and New in the Palestinian Holocaust Public Discourse,” Journal for the Study of Antisemitism 7, no. 2 (2015): 203-20. 
should be noted that simultaneously they still arouse public resentment. In December 2017, for example, a Holocaust exhibition was inaugurated at the Tunisian National Library, but it was greeted with anger and protests. ${ }^{89}$ On the occasion of International Holocaust Memorial Day in January 27, 2018, the secretary general of the Muslim World League in Saudi Arabia, Muhammad bin abdel-Kareem Al-Issa, condemned Holocaust denial as a "crime that distorts history and an insult to the dignity of those innocent souls who have perished," in a letter to the US Holocaust Memorial Museum. ${ }^{90}$ In 2017, Menhaz Afridi, an Associate Professor of Religious Studies and director of the Holocaust, Genocide \& Interfaith Education Center in Manhattan College published her book Shoah Through Muslim Eyes, which is an account of her personal educational journey to learn about Jews, the Shoah, and Judaism, sparked by her desire "to understand 'the other'." Fatigued by antisemitism and Islamophobia, Afridi wanted to offer Muslim readers "a different perspective" by deconstructing pervasive misconceptions about the Holocaust and the Jews, and "help to create a dialogue about pain and suffering of the 'other'." 91

Another remarkable trend is the renewed interest in the history of the Jews in Arab lands among Arab scholars, writers and documentarians, which already led to joint meetings between Iraqi intellectuals and poets and Israelis and Jews; ${ }^{92}$ conferences such as the one held in Berlin in October 2017 on "the Jews in majority Muslim Countries-History and Prospects;"93 documentaries recreating Jewish life in Egypt and penetrating discussions of the reasons for the demise of the Jewish communities in Arab countries and its detrimental consequences

89 "Protesters Smash Holocaust Exhibition at National Library of Tunisia: Holocaust Was a Myth and a Lie,” Memri, Clip no. 6349, December 15, 2017, https://www.memri.org/tv/protest ers-smash-holocaust-exhibition-in-tunisia-holocaust-was-myth-and-lie. See also Memri, Special Dispatch, no. 7262, January 3, 2018, https://www.memri.org/reports/protesters-smash-hol ocaust-exhibition-national-library-tunisia-holocaust-was-myth-and-lie.

90 R. Satloff, “A Historic Holocaust Awareness Awakening in Saudi Arabia, of All Places,” New York Daily News, January 26, 2018, http://www.washingtoninstitute.org/policy-analysis/view/ahistoric-holocaust-awareness-awakening-in-saudi-arabia-of-all-places; Al-Sharq al-Awsat, January 27, 2018, https://aawsat.com/print/1156256; M. Sones, "Saudi Cleric: 'Holocaust Denial a Crime that Distorts History'," Israel National News, January 30, 2018, https://www.israel nationalnews.com/News/ News.aspx/241361.

91 M. M. Afridi, Shoah Through Muslim Eyes (Boston: Academic Studies Press, 2017), 210. 92 H. Pedaya, "Baghdad,” Haaretz, January 26, 2018.

93 R. Qamari, "The History and Life of the Jews in Arab and Islamic Societies at a Conference in Berlin,” al-Mughared, November 13, 2017, http://almughared.com/arabjews/13112017-17613. 
to Arab societies. ${ }^{94}$ The Iraqi site, Imara wa-Tijara, introduced a four-part article on the penetration of antisemitism in the Middle East, ${ }^{95}$ and posted an Arabic book from the 1920s on the The Jewish Revival and its Eternal History (al-nahdha al-'isra'iliyya wa-tarikhuha al-khalid), ${ }^{96}$ as well as the Arabic translation of The journey of Rabbi Benjamin Tudela (Rihlat Binyamin) in the Middle East in the twelfth century. The book was translated in Bagdad in 1945, with an introduction of an Arab historian 'Abbas al-'Azzawi. ${ }^{97}$

These trends, which are still in the bud, lead me to believe that spreading knowledge is the most effective tool for fighting prejudice and antisemitism. This approach should include learning about Jewish life in Arab lands, learning about the Holocaust, and holding interfaith dialogues that would facilitate a fresh re-interpretation of religious sources. "This provides the ability to deal with texts that run contrary to what we regard as the fundamental values of our tradition," as Prince Hassan of Jordan asserted..$^{98}$ Muslims and Jews

have much in common and can benefit from mutual understanding and cooperation, and it will be of benefit for all parties when Muslims and Jews can work together consistently and reliably. But working together requires that both communities take stock of their own prejudice against the other and work to resolve it. ${ }^{99}$

Dr. Esther Webman is a senior research fellow at the Dayan Center for Middle Eastern and African Studies at Tel Aviv University. She is the Academic Adviser to the Program for the Study of Jews in Arab Lands, and serves as a member of the editorial boards of Moreshet, an Hebrew-English Journal for the Study of the Holocaust and Antisemitism, and Antisemitism Studies. Her research focuses on Arab discourse analysis, particularly Arab Antisemitism and Arab perceptions of the Holocaust.

94 See for example, A. Ramses, "Jews of Egypt," filmed 2012, video, 1:36:04, https://www.you tube.com/watch?v=UB1oFW-lrHA; "Muslims in Egypt Are Trying to Preserve its Jewish Heritage," The Economist, September 9, 2017, https://www.economist.com/middle-east-and-africa/2017/09/ 09/muslims-in-egypt-are-trying-to-preserve-its-jewish-heritage.

$95 \mathrm{http} / / /$ www.imarawatijara.com/antisemitismmiddleeast/.

$96 \mathrm{http}: / /$ www.imarawatijara.com/nahdha_israeliya.pdf.

$97 \mathrm{http} / / / 02 \mathrm{e} 37 \mathrm{fc}$. netsolhost.com/site/benjamintudela.pdf.

98 Prince Hassan of Jordan and E. Kessler, "Muslims and Jews Must Combine to Champion Tolerance and Stop the Isil-Inspired Hatred across the Middle East,” The Telegraph, August 23, 2016, http://www.telegraph.co.uk/news/2016/08/23/muslims-and-jews-must-combine-to-champion-tol erance-and-stop-the/.

99 Firestone, "Islamophobia and Anti-Semitism," 50. 


\section{Bibliography}

'Abd al-Rahman, W. "The Mufti of Jordan: The "Ulama Should Agree on One Discourse to Fight the Takfiri Thinking." al-Sharq al-Awsat, December 21, 2014.

Afridi, Mehnaz Mona. Shoah Through Muslim Eyes. Boston: Academic Studies Press, 2017. al-Hayat. February 24, 1998.

al-Hayat. March 15, 2015.

al-Hufni, 'Abd al-Mun'im. A World Without Jews. [In Arabic.] Cairo: Dar al-Rashad, 1992.

al-Ibrahim, Bader. "ISIS, Wahhabism and Takfir." Contemporary Arab Affairs 8, no. 3 (JulySeptember 2015): 408-15.

al-Qahtani, Saud. al-Jazira, July 23, 2016.

Al-Quds al-'Arabi. February 23, 1998.

Al-Quds al-'Arabi. February 21, 2003.

Al-Sharq al-Awsat, January 27, 2018. https://aawsat.com/print/1156256.

Ali, Ameer. "From Islamophobia to Westophobia: The Long Road to Radical Islamism." Journal of Asian Security and International Affairs 3, no. 1 (2016): 1-19.

Anti-Defamation League. "Claims That ISIS Has Jewish Roots Grow In Muslim World." August 26, 2015. http://blog.adl.org/intenational/claims-that-isis-has-jewish-roots-grow-in-mus lim-world.

Ayoob, Mohammed. "Challenging Hegemony: Political Islam and the North-South Divide." International Studies Review 9 (2007): 629-43.

Ayubi, Nazih. Political Islam: Religion and Politics in the Arab World. London: Routledge, 1991.

Bale, Jeffrey M. "Islamism and Totalitarianism." Totalitarian Movements and Political Religions 10, no. 2 (June 2009): 73-96.

Bayat, Asef. "Islamism and Empire: The Incongruous Nature of Islamist Anti-Imperialism." Socialist Register 44 (2008): 38-54.

Bennoune, Karima. Your Fatwa Does not Apply here: Untold Stories from the Fight against Muslim Fundamentalism. New York: W. W. Norton, 2013.

Bostom, Andrew G., ed. The Legacy of Islamic Antisemitism. From Sacred Texts to Solemn History. New York: Prometheus Books, 2008.

Calvert, John. Sayyid Qutb and the Origins of Radical Islamism. London: Hurst, 2010.

Commins, David. The Wahhabi Mission and Saudi Arabia. London: I. B. Tauris, 2016.

Confino, Alon. A World Without Jews: The Nazi Imagination from Persecution to Genocide. New Haven: Yale University Press, 2014.

Devji, Faisal. "Al-Qaeda, Spectre of Globalisation." Soundings, A Journal of Politics and Culture, 32 (Spring 2006): $18-27$.

Devji, Faisal, and Jason Bahbak Mohaghegh. "Point of No Return: Extremism, Sectarian Violence, and the Militant Subject." Journal of the Society for Contemporary Thought and the Islamicate World Interlocutors Series, SCTIW Review (September 3, 2014).

Ebstein, Michael. In the Shadows of the Koran: Said Qutb's Views on Jews and Christians as Reflected in his Koran Commentary. Washington: Hudson Institute, 2009.

Firestone, Reuven. "Contextualizing Antisemitism in Islam: Choseness, Choosing, and the Emergence of New Religion." In Not Your Father's Antisemitism: Hatred of the Jews in the Twenty-first Century, edited by Michael Berenbaum, 119-40. St. Paul: Paragon House, 2008. 
Firestone, Reuven. "Islamophobia \& Anti-Semitism: History and Possibility." Arches Quarterly 4, edition 7 (Winter 2010): 42-53.

Fishman, Brian H. The Master Plan: ISIS, al-Qaeda, and the Jihadi Strategy for Final Victory. New Have and London: Yale University Press, 2016.

Haim, Sylvia G. "Arabic Antisemitic Literature. Some Preliminary Notes.” Jewish Social Studies 17, no. 4 (October 1995): 307-12.

Haim, Sylvia G. "The Palestine Problem in al-Manar." In Egypt and Palestine: A Millennium of Association (868-1948), edited by Amnon Cohen and Gabriel Baer, 229-313. Jerusalem: Yad Izhak Ben-Zvi, 1984.

Hasan, Mehdi. "How Islamic Is the Islamic State? Not at all. What the Atlantic Got Wrong about ISIS." The New Republic, March 13, 2015. https://newrepublic.com/article/121286/ how-islamic-islamic-state.

Hassan, Prince of Jordan, and Ed Kessler. "Muslims and Jews Must Combine to Champion Tolerance and Stop the Isil-Inspired Hatred across the Middle East." The Telegraph, August 23, 2016. http://www.telegraph.co.uk/news/2016/08/23/muslims-and-jews-mustcombine-to-champion-tolerance-and-stop-the/.

Heni, Clemens. Antisemitism: A Specific Phenomenon: Holocaust Trivialization-IslamismPost-colonial and Cosmopolitan anti-Zionism. Berlin: Edition Critic, 2012.

Herf, Jeffrey. Nazi Propaganda for the Arab World. New Haven: Yale University Press, 2009.

Herf, Jeffrey. "Realism, Islamism, and Counterterrorism." The National Interest, June 7, 2017. http://www.meforum.org/6755/realism-islamism-and-islam-when-will-difficult.

Hijazi, Y. al-Jazira, July 30, 2016.

Hourani, Albert. Arabic Thought in the Liberal Age 1798-1939. London: Oxford University Press, 1970.

Hugi, Jacky. “Egyptian Intellectuals Call for Fresh Thinking about 'Jewish Question'.” al-Monitor, January 17, 2014. https://www.al-monitor.com/pulse/ru/originals/2014/01/ youssef-zeidan-intellectual-egypt-israel-relations.html.

Ibrahim, Raymond. “Egypt's Sisi: Islamic 'Thinking' is Antagonizing the Entire World.” Middle East Forum, January 1, 2015. https://www.meforum.org/articles/2015/egypt-s-sisi-islamicthinking-is-antagonizing.

Iranian Students' News Agency. "Veterans Today: Da'ish Leader is Jewish and a Mossad Agent," September 10, 2014, http://www.isna.ir/fa/news/93051607502/

Jansen, Johannes G. The Dual Nature of Islamic Fundamentalism. London: Hurst, 1997. Judaken, Jonathan. "So What's New? Rethinking the 'New Antisemitism' in a Global Age." Patterns of Prejudice 42, nos. 4-5 (2008): 531-60.

Karsh, Efraim. "The Long Trail of Islamic Antisemitism." in Islamic Attitudes to Israel, edited by Efraim Karsh and P. R. Kumaraswamy, 1-12. Milton Park: Routledge, 2008.

Kenney, Jeffrey T. "Enemies Near and Far: The Image of the Jews in Islamist Discourse in Egypt.” Religion 24, no. 3 (1994): 253-70.

Kerr, Malcolm H. Islamic Reform: The Political and Legal Theories of Muhammad 'Abduh and Rashid Rida. Berkeley: University of California Press, 1966.

Kramer, Martin, ed. The Islamism Debate. Tel Aviv: Tel Aviv University, 1997.

Krämer, Gudrun. "Antisemitism in the Muslim World. A Critical Review." Die Welt des Islams 46, no. 3 (November 2006): $243-76$.

Kressel, Neil J. "The Sons of Pigs and Apes": Muslim Antisemitism and the Conspiracy of Silence. Washington: Potomac Books, 2012. 
Küntzel, Matthias. Jihad and Jew-Hatred: Islamism, Nazism and the Roots of 9/11. New York: Telos, 2007.

Küntzel, Matthias. "The Roots of Antisemitism in the Middle East: New Debates." In Resurgent Antisemitism: Global Perspectives, edited by Alvin H. Rosenfeld, 382-98. Indiana: Indiana University Press, 2013.

Landau-Tasseron, Ella. "Delegitimizing ISIS on Islamic Grounds: Criticism of Abu Bakr al-Baghdadi by Muslim Scholars." Memri. Inquiry and Analysis, no. 1205, November 19, 2015. http://www.memri.org/publicdocs/MEMRI_IA_1205_Delegitimizing_ISIS _On_Islamic_Grounds-FINAL.pdf.

Lewis, Bernard. "License to Kill: Usama bin Ladin's Declaration of Jihad." Foreign Affairs 77, no. 6 (November-December 1998): 9-14.

Lewis, Bernard. Semites and Antisemites. London: Phoenix Giant, 1997.

Lilla, Mark. The Shipwrecked Mind. New York: The New York Review of Books, 2016.

Litvak, Meir, and Esther Webman. מאמפתיה להכחשה: תגובות לשואה בעולם הערבי (Me'empatyah lehakhhashah: teguvot laShoah ba'olam ha'aravi) [From Empathy to Denial: Arab Responses to the Holocaust]. Jerusalem: The Hebrew University Magnes Press, 2015.

Mabon, Simon, and Stephan A. Royal. The Origins of ISIS: The Collapse of Nations and Revolution in the Middle East. London: I. B. Tauris, 2017.

Maqdsi, Muhammad. "Charter of The Islamic Resistance Movement (Hamas) of Palestine." Journal of Palestine Studies 22, no. 4 (Summer, 1993): 122-34.

Melhem, Hisham. "The Barbarians Within Our Gates." Politico Magazine, September 18, 2014. https://www.politico.com/magazine/story/2014/09/the-barbarians-within-ourgates-111116.

Memri. Clip no. 4546. "Syrian Minister of Culture Issam Khalil: Jehovah and ISIS Use the Same Terrorist Methods.” October 3, 2014. http://www.memritv.org/clip_transcript/en/ 4546.htm.

Memri. Clip no. 6185. "Syrian Poet Adonis: There Can Be No Democracy in the Arab World under Present Circumstances.” August 11, 2017. https://www.memri.org/tv/syrian-poetadonis-no-democracy-in-arab-world-people-undergoing-extinction.

Memri, Clip no. 6408. "Egyptian MP Nashwa Al-Dib: Abolish the 'Shameful' Peace Accords." January 3, 2018. https://www.memri.org/tv/egyptian-mp-nashwa-dib-abolish-shamefulegypt-israel-peace-accords/transcript.

Memri. Clip no. 6349. "Protesters Smash Holocaust Exhibition at National Library of Tunisia: Holocaust Was a Myth and a Lie." December 15, 2017. https://www.memri.org/tv/protest ers-smash-holocaust-exhibition-in-tunisia-holocaust-was-myth-and-lie.

Memri. Special Dispatch 476. "Bin Laden's Sermon for the Feast of the Sacrifice." March 6, 2003. https://www.memri.org/reports/bin-ladens-sermon-feast-sacrifice.

Memri. Special Dispatch, no. 5910. "Al-Azhar: The Islamic State (ISIS) is a Terrorist Organization, but it Must not be Accused of Heresy." December 21, 2014. https://www. memri.org/reports/al-azhar-islamic-state-isis-terrorist-organization-it-must-not-be-ac cused-heresy.

Memri. Special Dispatch, no. 6574. "Articles in Saudi Press: End the Antisemitic Discourse, Learn from the Jews' Success." August 14, 2016. https://www.memri.org/reports/ar ticles-saudi-press-end-antisemitic-discourse-learn-jews-success-0.

Memri. Special Dispatch no. 6890. "Jordanian Columnist in Muslim Brotherhood Daily: A Million Hitlers From all over the World Will Appear and Eliminate The Jews." April 23, 
2017. https://www.memri.org/reports/jordanian-columnist-al-shawaheen-two-antisemiticarticles.

Memri. Special Dispatch, no. 7262. "Protesters Smash Holocaust Exhibition At National Library Of Tunisia: Holocaust Was A Myth And A Lie.” January 3, 2018. https://www. memri.org/reports/protesters-smash-holocaust-exhibition-national-library-tunisia-hol ocaust-was-myth-and-lie.

Memri. Special Dispatch no. 7346. "Imam Al-Rawashdeh in Jordan Friday Sermon Says Allah Gathered the Jews in Palestine so They Could Be Annihilated." February 21, 2018. https://www.memri.org/reports/imam-al-rawashdeh-jordan-friday-sermon-says-allah-gath ered-jews-palestine-so-they-could-be.

Mirsepassi, Ali. "Religious Intellectuals and Western Critiques of Secular Modernity." Comparative Studies of South Asia and the Middle East 26, no. 3 (2006): 416-33.

Mitchell, Richard Paul. The Society of the Muslim Brothers. New York: Oxford University Press, 1993.

N. N. "Daish: Allah Did Not Order Us to Fight Israel." al-Masri al-Yawm, July 9, 2014. http:// www.almasryalyoum.com/news/details/479626.

N. N. "Muslims in Egypt Are Trying to Preserve its Jewish Heritage." The Economist, September 9, 2017. https://www.economist.com/middle-east-and-africa/2017/09/09/mus lims-in-egypt-are-trying-to-preserve-its-jewish-heritage.

Nettler, Roland L. Past Trials and Present Tribulations: A Muslim Fundamentalist's View of the Jews. Jerusalem: Pergamon, 1987.

Nicosia, Francis R., and Boğaç A. Ergene, eds. Nazism, The Holocaust, And The Middle East: Arab and Turkish Responses. New York: Berghahn Books, 2018.

Nirenberg, David. Anti-Judaism: The Western Tradition. New York: W. W. Norton, 2013.

Paterson, David. "The Muslim Brotherhood and the Evolution of Jihadist Antisemitism." ISGAP Flashpoint 50, January 17, 2018. https://isgap.org/flashpoint/the-muslim-brotherhoodand-the-evolution-of-jihadist-antisemitism/.

Pedaya, Haviva. "Baghdad." Haaretz, January 26, 2018.

Porat, Dina, ed. Antisemitism Worldwide, General Analysis 2015. Tel Aviv: Tel Aviv University, Kantor Center 2016. http://kantorcenter.tau.ac.il/sites/ default/files/Doch2015-\%20\% 28160117\%29.pdf.

Qamari, Riem. "The History and Life of the Jews in Arab and Islamic Societies at a Conference in Berlin." Al-Mughared, November 13, 2017. http://almughared.com/arabjews/ 13112017-17613.

Qutb, Sayyid. "The America I Have Seen.” Al-Risala, November 5, 1951, 1245-1247; Al-Risala, November 19, 1951, 1301-6; Al-Risala, December 3, 1951, 1357-60.

Qutb, Sayyid. "The American Conscience....and the Palestinian Case.” al-Risala, no. 697. October 21, 1946.

Ramses, Ameer. “Jews of Egypt.” Filmed 2012. Video, 1:36:04. https://www.youtube.com/ watch?v=UB10FW-IrHA.

Rida, Rashid. "A Lecture at The Association of Muslim Youth," al-Manar 34 (1934).

Rida, Rashid. "The Jews in France and in Egypt." al-Manar 1, no. 2 (1898): 35-55.

Rida, Rashid. "The Life of a Nation After Its Death." al-Manar 4, no. 21 (1902): 801-9.

Rodenbeck, Max. "The Truth About Jihad." The New York Times Review of Books, August 11, 2005. http://www.nybooks.com/articles/2005/08/11/the-truth-about-jihad/. 
Rogers, Paul. Irregular War: ISIS and the New Threat from the Margins. London: I. B. Tauris, 2016.

Roy, Olivier. Globalised Islam: The Search for a New Ummah. London: Hurst, 2004.

Roy, Olivier. "Who Are the New Jihadis?" The Guardian, April 13, 2017.

Ryan, Michael. Decoding Al-Qaeda's Strategy: The Deep Battle Against America. New York: Columbia University Press, 2017.

Safran, Nadav. Egypt in Search of Political Community. Cambridge and London: Harvard University Press, 1961.

Satloff, Robert. "A Historic Holocaust Awareness Awakening in Saudi Arabia, of All Places," New York Daily News, January 26, 2018. http://www.washingtoninstitute.org/policy-analy sis/view/a-historic-holocaust-awareness-awakening-in-saudi-arabia-of-all-places;

Ser, Sam. "A Simmering Hatred, Interview with Andrew G. Bostom." The Jerusalem Post, June 20, 2008. https://www.andrewbostom.org/2008/06/jerusalem-post-interview-with-samser/.

Shawaheen, Jamal. "The Jewish Entity [Is] the Problem of the Whole World." al-Sabil, March 18, 2017.

Sivan, Emmanuel. "Islamic Fundamentalism, Antisemitism and Anti-Zionism." In Anti-Zionism and Antisemitism in the Contemporary World, edited by Roland S. Wistrich, 74-84. London: Macmillan, 1990.

Sivan, Emmanuel. Radical Islam, Medieval Theology and Modern Politics. New Haven: Yale University Press, 1985.

Sivan, Emmanuel. “A Resurgence of Arab Antisemitism?” In Survey of Jewish Affairs, 1988, edited by William Frankel, 78-95. London: Associated University Presses, 1989.

Smith, David Norman. "The Social Construction of Enemies: Jews and the Representation of Evil." Sociological Theory 14, no. 3 (November 1996): 203-40.

Sones, Mordechai. "Saudi Cleric: 'Holocaust Denial a Crime that Distorts History'." Israel National News, January 30, 2018. http://www.israelnationalnews.com/News/News.aspx/ 241361.

Speyer, Lea. “Prominent American Islamic Scholar Calls 'Horrific' Antisemitism Rampant among Muslims Antithetical to their Religion.” Algemeiner, January 3, 2017. https://www. algemeiner.com/2017/01/03/prominent-american-islamic-scholar-calls-horrific-anti semitism-rampant-among-muslims-antithetical-to-their-religion/.

Tibi, Bassam. "From Sayyid Qutb to Hamas: The Middle East Conflict and the Islamization of Antisemitism." In Global Antisemitism: A Crisis of Modernity IV, edited by Charles Asher Small, 4-26. New York: ISGAP, 2013.

'Uwaysī, 'Abd al-Fattāḥ Muḥammad. The Muslim Brothers and the Palestine Question 1928-1947. London: Taurus Academic Studies, 1998.

Valentine, Simon Ross. Force and Fanaticism: Wahhabism in Saudi Arabia and Beyond. London: Hurst, 2015.

Webman, Esther. “Al-Qa'ida and the 'Arab Spring': Redefining Its Modus-Operandi.” Tel Aviv Notes 6, no. 23, December 10, 2012. https://dayan.org/content/tel-aviv-notes-al-qaidaand-arab-spring-redefining-its-modus-operandi.

Webman, Esther. "The Challenge of Assessing Arab/Islamic Antisemitism." Middle East Studies 46, no. 5 (September 2010): 677-97.

Webman, Esther. "From the Damascus Blood Libel to the 'Arab Spring': The Evolution of Arab Antisemitism.” Antisemitism Studies 1, no. 1 (Spring 2017): 157-206. 
Webman, Esther. "Old and New in the Palestinian Holocaust Public Discourse." Journal for the Study of Antisemitism 7, no. 2 (2015): 203-20.

Webman, Esther. "The Polarization and Radicalization of Political Islam." In Middle East Contemporary Survey, XXII: 1998, edited by Bruce Maddy-Weitzman, 129-31. Boulder: Westview, 2001.

Webman, Esther. "Treading in Troubled Waters: Seeking the Roots of Muslim Antisemitism." Bustan. The Middle East Book Review 4, no. 2 (2013): 113-36.

Wien, Peter. "There is no Tradition of anti-Semitism in Islam." Qantara, May 23, 2018. https://en.qantara.de/content/anti-semitism-there-is-no-tradition-of-anti-semitism-inislam.

Wild, Stefan. "Islamofascism?: Introduction." Die Welt des Islams: International Journal for the Study of Modern Islam 52, nos. 3-4 (2012): 225-41.

Wistrich, Robert S. "Anti-Zionist Connections: Communism, Radical Islam, and the Left." In Resurgent Antisemitism: Global Perspectives, edited by Alvin H. Rosenfeld, 402-23. Indiana: Indiana University Press, 2013.

Wood, Graeme. "What ISIS Really Wants.” Atlantic, March 2015. https://www.theatlantic.com/ magazine/archive/2015/03/what-isis-really-wants/384980/.

Zubaida, Sami. “Trajectories of Political Islam.” Index of Censorship 4 (1996): 150-57. 
